CONCISE REPORT

\title{
Increased matrix concentrations of IGFBP-5 in cancellous bone in osteoarthritis
}

\author{
C A Sharp, S J Brown, M W J Davie, P Magnusson, S Mohan
}

Ann Rheum Dis 2004;63:1162-1165. doi: 10.1136/ard.2003.013920

Background: In osteoarthritis cancellous bone adapts to meet altered mechanical loading. These changes may be mediated by insulin-like growth factors (IGF-I and IGF-II), but the matrix bound binding protein, IGFBP-5 has not been investigated. Objectives: To measure IGF-I, IGF-II, and IGFBP-5 in femoral head bone from non-OA controls and patients with $O A$, and to relate these to apparent density $\left(\rho_{A}\right)$ and elastic modulus (Ec).

Methods: $\rho_{\mathrm{A}}, \mathrm{Ec}$, and IGF system components were measured in cancellous bone from superior and inferior regions of femoral heads from 31 patients with $O A$ and 11 age selected controls.

Results: Ec and $\rho_{A}$ were greater $(p<0.05)$ in the superior region of all femoral heads. In primary $O A, \rho_{A}$ was increased in the inferior region $(p<0.05)$. IGFBP-5 was increased, about twofold, at superior and inferior regions in primary OA ( 1.60 and $1.54 \mathrm{ng} / \mathrm{mg}$ bone, respectively, both $\mathrm{p}<0.05)$ and in Paget's disease $(2.44$ and $1.75 \mathrm{ng} / \mathrm{mg}$ bone, both $\mathrm{p}<0.05)$ compared with controls $(0.73$ and $0.95 \mathrm{ng} / \mathrm{mg}$ bone). In controls, inverse correlations between IGFBP-5 and both $\rho_{\mathrm{A}}$ and Ec at superior $\left(r_{\mathrm{s}}=-0.64\right.$ and -0.73 , both $p<0.05)$ and inferior regions $\left(r_{s}=-0.72\right.$, $p<0.05$ and -0.24 (NS)) were seen, but these were lost in $\mathrm{OA}$.

Conclusions: IGFBP-5 may modulate cancellous bone formation by negative feedback. In end stage OA this is disrupted, but has little influence on material properties.

$\mathrm{T}$ he osteoarthropathies are common disorders in Western societies, with knee and hip osteoarthritis (OA) affecting $10-25 \%$ of people in retirement. OA can be classified as primary when the diagnosis excludes secondary factors, such as Paget's disease, at adjacent skeletal sites that affect the joint. In the hip, end stage OA is characterised by progressive changes to the cartilage, the underlying calcified cartilage, and the cancellous bone network.

Investigations of the material and compositional properties of OA bone suggest increased proportions of less-well mineralised bone ${ }^{12}$ with structural changes to the cancellous network that are different from, and in some respects opposite to, those associated with healthy aging. ${ }^{3}$ The amount of bone present, expressed as apparent density, is important because it is a major determinant of the mechanical competence of bone. ${ }^{4}$ Cancellous bone from femoral heads affected by end stage OA has greater apparent density but is no stiffer than healthy bone. ${ }^{12}$

Gross structural changes to the cancellous network are the result of increased bone cell activity and matrix turnover. ${ }^{56}$ The factors that mediate these processes in bone are uncertain. The insulin-like growth factors (IGFs) are some of the most abundant factors produced by bone cells and have been implicated in maintaining bone mass in OA. ${ }^{7}$ IGFs are stored in human bone matrix mainly through their low affinity interaction with IGF binding protein 5 (IGFBP-5). ${ }^{8}$ In bone, IGFBP-5 not only limits the availability of IGF with its receptor, thus modulating IGF actions at the tissue level, but also has stimulatory effects on osteoblasts that are independent of IGF. ${ }^{9}$ To date the matrix associated IGFBPs have not been studied in OA bone. Here we have investigated bone matrix concentrations of IGF-I, IGF-II and, for the first time, their matrix bound binding protein IGFBP-5 in cancellous bone cores sampled from two differently loaded regions of the femoral head in subjects with primary and secondary OA, and in an age selected healthy control group. These have been related to material and mechanical measurements.

\section{PATIENTS AND METHODS}

Proximal femora were obtained postoperatively (mostly OA) and at necropsy (mostly healthy). After removal, all samples were stored frozen and precautions taken to minimise deterioration and dehydration. Visual examination and radiographs of the femoral heads were combined with clinical records, where available, to group the bones into those with no overt bone or joint disease and those affected by OA. OA was defined by the presence of typical visible features, including fibrillation and wear of the articular cartilage, eburnation and pitting of the subchondral bone, and gross changes such as femoral head deformation and osteophytes. The presence of other bone and joint related disorders was identified from clinical notes.

Cancellous bone cores ( $12 \mathrm{~mm}$ diameter) from the superior and inferior regions were taken perpendicular to the axis of coronal sections (approx $16 \mathrm{~mm}$ ) cut through the centre of the intact femoral head, cleaned by water jetting, and defatted. ${ }^{2}$ Physical and biochemical measurements were performed on most of the cores obtained from 42 subjects aged between 50 and 90 years and classified as healthy $(\mathrm{n}=11,7$ male/4 sex unknown), end stage primary OA ( $\mathrm{n}=21,7$ male/1 1 female $/ 3$ unknown), and OA secondary to Paget's disease $(\mathrm{n}=7,4$ male/ 3 female) and ankylosing spondylitis ( $\mathrm{n}=3$, 1 male $/ 2$ unknown) at sites adjacent to, or other than the femoral head. Apparent density $\left(\rho_{A}, \mathrm{~g} / \mathrm{cm}^{3}\right)$ was calculated from the hydrated tissue weights and gross volumes of the bone cores, and stiffness (Ec, MPa) by unconfined compression tests. ${ }^{2}$

Each bone core was then powdered under liquid nitrogen, defatted, and lyophilised. Chemical analyses were made on weighed samples of dried bone powder. IGF-I, IGF-II, and IGFBP-5 were extracted from washed bone powders by demineralisation under dissociative conditions (0.5M EDTA, $4 \mathrm{M}$ guanidine- $\mathrm{HCl}$, and protease inhibitors in $30 \mathrm{mM}$ Tris$\mathrm{HCl}, \mathrm{pH}$ 7.4). This was repeated four times. Extracts were

Abbreviations: Ec, elastic modulus; IGF, insulin-like growth factor; IGFBP-5, insulin-like growth factor binding protein-5, OA, osteoarthritis; $\rho_{A}$, apparent density 
pooled and dialysed (Spectraphor No 3, $3500 \mathrm{Mr}$ cut off point) against $20 \mathrm{mM}$ acetic acid. Dialysed samples were transferred to $15 \mathrm{ml}$ polypropylene tubes and their volumes adjusted to $10 \mathrm{ml}$ with $20 \mathrm{mM}$ acetic acid. A $5 \mathrm{ml}$ aliquot was subjected to speed vacuum centrifugation and reconstituted with $500 \mu \mathrm{l}$ of $1 \mathrm{M}$ acetic acid and subjected to Bio-Spin separation using Bio-gel P-10 to separate the IGFs from their binding proteins. ${ }^{10} 11$ The IGF pool was then neutralised and used for IGF-I, IGF-II, and IGFBP-5 determination by validated radioimmunoassays. ${ }^{811}$

The Mann-Whitney U test was used to test for differences between and within groups, and Spearman rank for correlations. Biochemical findings are expressed as mass of analyte per mg of dry bone powder (ng/mg bone powder). Data are presented as medians with ranges, and significance defined as $\mathrm{p} \leqslant 0.05$. Groups are defined as healthy controls, primary OA, secondary OA, and a combined OA group-the sum of those with primary and secondary OA. The study was approved by the hospital research committee and was conducted in accordance with the Declaration of Helsinki.

\section{RESULTS}

\section{Comparison of superior and inferior regions}

IGF-II concentrations were consistently greater (approximately threefold) than those of IGF-I in all the bones examined. No differences in the concentrations of the IGF system components were found between the superior and inferior regions in either the controls or individual joint disease groups except for the combined OA group where IGFII concentrations were greater $(p=0.03)$ in the superior region (table 1). In all groups, values for both $\rho_{\mathrm{A}}$ and Ec were greater $($ all $\mathrm{p}<0.05)$ at the superior region (table 1 ).

\section{Comparison of the healthy and joint disease groups}

Approximately twofold more IGFBP-5 was extracted from both superior $(p=0.0002)$ and inferior regions $(p=0.004)$ of the combined OA group than from controls. IGFBP-5 was similarly increased in the primary OA $(p<0.0001$ and $\mathrm{p}=0.004$ respectively) and Paget's disease $(\mathrm{p}=0.017$ and $\mathrm{p}=0.037$ respectively) groups (table 1 ). IGFBP-5 in those with ankylosing spondylitis was not markedly different in either region $(0.98$ (0.4-3.0) and 1.05 (0.4-1.8) ng/mg, respectively) from controls.
In the primary $\mathrm{OA}$ and combined OA groups median values for $\rho_{A}$ were increased in both superior and inferior regions compared with controls, but differences were significant only at the inferior regions $(p=0.01$ and $p=0.035$, respectively) (table 1). Values for Ec did not differ significantly between groups.

\section{Relationships between IGF system components and $\rho_{A}$ and Ec}

In controls, strong inverse relationships were found between IGFBP-5 and $\rho_{\mathrm{A}}$ at both superior $\left(r_{\mathrm{s}}=-0.64, \mathrm{p}=0.048\right)$ and inferior regions $\left(r_{\mathrm{s}}=-0.72, \mathrm{p}=0.013\right)$ (fig 1). Similar trends with Ec were also found at these sites $\left(r_{\mathrm{s}}=-0.73, \mathrm{p}=0.016\right.$ and $r_{\mathrm{s}}=-0.24, \mathrm{p}=0.48$, respectively) (fig 2). No significant associations were found in either the primary or secondary OA groups.

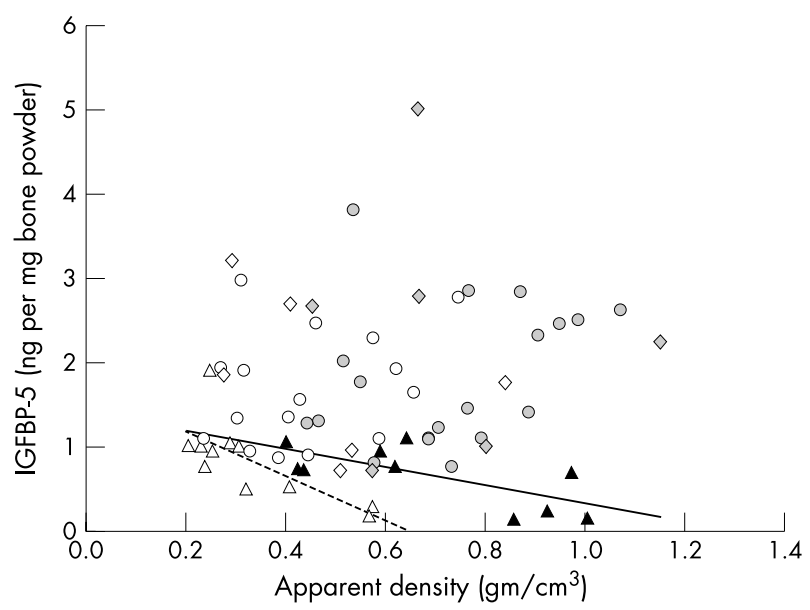

Figure 1 Relationships between $\rho_{A}$ of the bone cores and IGFBP-5 extracted from the bone matrix. Triangles = healthy controls, circles $=$ primary OA, diamonds $=$ secondary OA (Paget's disease). Open symbols represent inferior and closed symbols the superior regions. Solid and broken lines illustrate linear correlations in the superior and inferior regions of the healthy control group, respectively.

Table 1 Summary of the material and physical properties of the cancellous bone cores and concentrations of the IGF system components measured in extracts of bone sampled from the superior and inferior regions of femoral heads

\begin{tabular}{|c|c|c|c|c|c|c|c|c|c|}
\hline \multicolumn{2}{|l|}{$\begin{array}{l}\text { IGFBP-5 } \\
\text { (ng/mg bone) }\end{array}$} & \multicolumn{2}{|c|}{$\begin{array}{l}\text { IGF-I } \\
\text { (ng/mg bone) }\end{array}$} & \multicolumn{2}{|c|}{$\begin{array}{l}\text { IGF-II } \\
\text { (ng/mg bone) }\end{array}$} & \multicolumn{2}{|c|}{$\begin{array}{l}\text { Apparent density } \\
\left(\mathrm{g} / \mathrm{cm}^{3}\right)\end{array}$} & \multicolumn{2}{|l|}{$\begin{array}{l}\text { Stiffness } \\
\text { (MPa) }\end{array}$} \\
\hline Superior & Inferior & Superior & Inferior & Superior & Inferior & Superior & Inferior & Superior & Inferior \\
\hline $\begin{array}{l}\text { Healthy } \\
0.73 \\
(0.14-1.10) \\
10\end{array}$ & $\begin{array}{l}0.95 \\
(0.18-1.90) \\
11\end{array}$ & $\begin{array}{l}0.06 \\
(0.02-0.11) \\
10\end{array}$ & $\begin{array}{l}0.06 \\
(0.04-0.09) \\
11\end{array}$ & $\begin{array}{l}0.21 \\
(0.05-0.41) \\
10\end{array}$ & $\begin{array}{l}0.21 \\
(0.12-0.34) \\
11\end{array}$ & $\begin{array}{l}0.62+c \\
(0.40-1.01) \\
11\end{array}$ & $\begin{array}{l}0.29 \\
(0.20-0.57) \\
11\end{array}$ & $\begin{array}{l}247 \dagger c \\
(69-548) \\
11\end{array}$ & $\begin{array}{l}51 \\
(37-167) \\
11\end{array}$ \\
\hline $\begin{array}{l}\text { Primary OA } \\
1.60^{*} \mathrm{e} \\
(0.75-3.79) \\
18\end{array}$ & $\begin{array}{l}1.54^{*} b \\
(0.70-2.96) \\
17\end{array}$ & $\begin{array}{l}0.09 \\
(0.03-0.24) \\
18\end{array}$ & $\begin{array}{l}0.07 \\
(0.02-0.18) \\
17\end{array}$ & $\begin{array}{l}0.22 \\
(0.11-0.31) \\
18\end{array}$ & $\begin{array}{l}0.16 \\
(0.09-0.32) \\
17\end{array}$ & $\begin{array}{l}0.73+\mathrm{te} \\
(0.44-1.07) \\
21\end{array}$ & $\begin{array}{l}0.43^{*} a \\
(0.27-0.75) \\
19\end{array}$ & $\begin{array}{l}226+d \\
(40-598) \\
21\end{array}$ & $\begin{array}{l}58 \\
(8-298) \\
19\end{array}$ \\
\hline $\begin{array}{l}\text { Secondary } O A \\
2.44^{*} a \\
(0.70-4.99) \\
6\end{array}$ & $\begin{array}{l}\text { Paget's disease } \\
1.75^{*} \mathrm{a} \\
(0.70-3.19) \\
7\end{array}$ & $\begin{array}{l}e \\
0.06 \\
(0.02-0.06) \\
6\end{array}$ & $\begin{array}{l}0.05 \\
(0.02-0.16) \\
7\end{array}$ & $\begin{array}{l}0.23 \\
(0.19-0.32) \\
6\end{array}$ & $\begin{array}{l}0.20 \\
(0.17-0.29) \\
7\end{array}$ & $\begin{array}{l}0.66+a \\
(0.45-1.15) \\
7\end{array}$ & $\begin{array}{l}0.41 \\
(0.23-0.84) \\
7\end{array}$ & $\begin{array}{l}239+b \\
(154-791) \\
7\end{array}$ & $\begin{array}{l}58 \\
(23-151) \\
7\end{array}$ \\
\hline $\begin{array}{l}\text { Combined OA } \\
1.75^{*} \mathrm{~d} \\
(0.38-4.99) \\
27\end{array}$ & $\begin{array}{l}\text { roup } \\
1.54^{*} b \\
(0.38-3.19) \\
27\end{array}$ & $\begin{array}{l}0.08 \\
(0.02-0.24) \\
27\end{array}$ & $\begin{array}{l}0.05 \\
(0.02-0.18) \\
27\end{array}$ & $\begin{array}{l}0.22+a \\
(0.11-0.37) \\
27\end{array}$ & $\begin{array}{l}0.18 \\
(0.09-0.32) \\
27\end{array}$ & $\begin{array}{l}0.68+\mathrm{te} \\
(0.44-1.15) \\
31\end{array}$ & $\begin{array}{l}0.41^{*} a \\
(0.22-0.84) \\
29\end{array}$ & $\begin{array}{l}239+\mathrm{te} \\
(40-791) \\
31\end{array}$ & $\begin{array}{l}58 \\
(8-298) \\
29\end{array}$ \\
\hline
\end{tabular}

Data are presented as median values, ranges, and the number of subjects $(n)$. Differences between the healthy controls and OA groups are indicated by ${ }^{*}$, and between regions by $\dagger$. Levels of statistical significance are denoted by: $a, p<0.05 ; b, p<0.005 ; c, p<0.001 ; d, p<0.0005 ;$ and $e, p<0.0001$. 


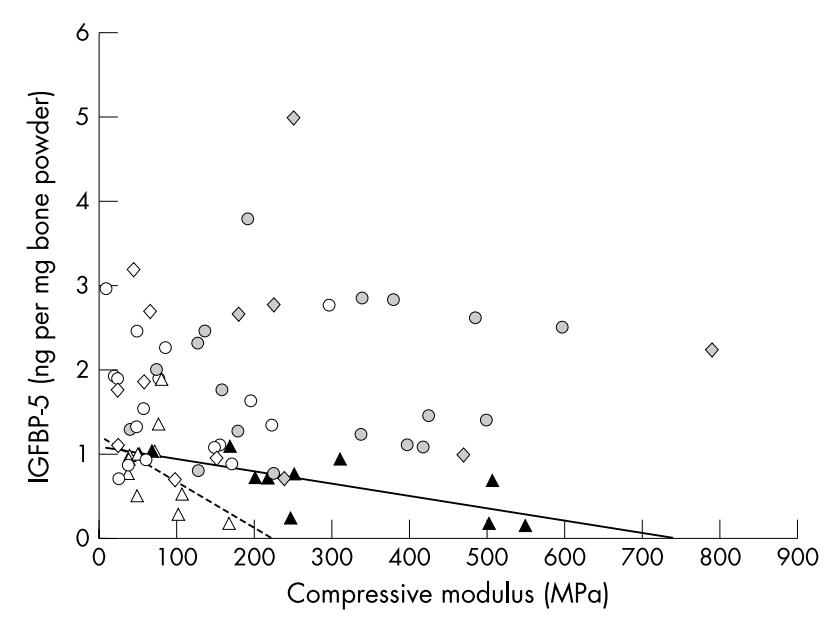

Figure 2 Relationships between the compressive modulus of the bone cores and IGFBP- 5 extracted from the bone matrix. Triangles = healthy controls, circles $=$ primary OA, diamonds = secondary OA (Paget's disease). Open symbols represent inferior and closed symbols the superior regions. Solid and broken lines illustrate linear correlations in the superior and inferior regions of the healthy control group, respectively.

\section{DISCUSSION}

Our finding of significantly increased $\rho_{\mathrm{A}}$ at the inferior sites of OA femoral heads supports previous work, ${ }^{1}$ and suggests bone formation within the OA femoral head. This may explain the observed changes in cancellous bone architecture. ${ }^{12}$ Bony changes may be partly explained by the known effects of the IGFs and IGFBP-5 on bone metabolism. Under normal conditions IGF activities are modulated by their interaction with binding proteins. IGFBP-4 is the major IGF binding protein produced in vitro by human osteoblasts and a potent inhibitor of IGF induced bone cell proliferation ${ }^{8}{ }^{13}$ and not measured in this study, In contrast with this, IGFBP-5 not only binds to and stores the IGFs in bone but also stimulates bone cell proliferation ${ }^{14}$ through both IGF dependent and IGF independent mechanisms. ${ }^{9}$ Here, and in contrast with other reports, ${ }^{7}$ both IGF-I and IGF-II were not significantly different in OA, but the relationships between the individual growth factors were conserved. However, we found approximately twofold more IGFBP-5 in extracts of femoral head cancellous bone from patients with end stage primary OA and in those with OA secondary to Paget's disease elsewhere in the skeleton than in healthy bones.

Accumulation of matrix IGFBP-5 may be accounted for by increased cellular production, reduced destruction, or decreased removal from bone. Alternatively, differences between the sources of the material may have influenced the stability of matrix bound IGFBP-5, leading to degradation of IGFBP-5 and loss of IGFBP-5 immunoreactivity in the healthy bones. Under appropriate conditions IGF binding proteins are degraded by IGFBP proteases, also produced by bone cells. ${ }^{15}$ However, it is unlikely that differences in IGFBP5 stability alone contribute to the findings reported here for the following reasons: firstly, much of the IGFBP-5 is embedded within the mineralised matrix which stabilises it and limits proteolytic degradation; secondly, the IGFBP-5 assay detects both intact and degraded fragments, and therefore limited proteolysis should not have significantly compromised the IGFBP-5 measurements in the necropsy samples; and thirdly, if IGFBP-5 in the necropsy specimens had degraded it might be expected that correlations would not be found between IGFBP- 5 and the material properties in this material.
We can speculate as to the physiological effects of increased IGFBP-5 in the matrix of OA bone. Firstly, in healthy bone, for which we have relatively few samples, inverse correlations between IGFBP-5 and $\rho_{\mathrm{A}}$ and Ec would be expected if IGFBP-5 were involved in the modulation of bone formation through a negative feedback mechanism. This hypothesis is supported by the loss of these correlations in OA bone (figs 1 and 2) indicating a breakdown of control, with increased IGFBP-5 responsible for maintaining $\rho_{A}$, possibly by stimulating bone formation and tissue deposition. Interestingly, our finding of inverse correlations with IGFBP-5 and material and mechanical parameters in healthy bone is supported by a recent study reporting similar findings between cortical bone IGFBP-5 and bone mineral density in postmenopausal women with osteoporosis. ${ }^{16}$ Secondly, if coupled bone turnover is increased, osteoclast mediated bone resorption may release matrix bound IGFBP-5 and other anabolic agents such as IGFs and transforming growth factor $\beta,{ }^{6}$ further potentiating bone cell activity. These factors may provide an environment which can maintain an active matrix producing osteoblastic phenotype that can respond to the altered dynamic loads experienced in joint disease by remodelling cancellous bone architecture.

In conclusion, we find increased matrix concentrations of IGFBP-5 at femoral head sites in end stage OA. Although this may preserve coupled bone remodelling and maintain bone mass, it does not necessarily improve bone strength.

\section{Authors' affiliations}

C A Sharp, S J Brown, M W J Davie, Charles Salt Centre, Robert Jones and Agnes Hunt Orthopaedic Hospital NHS Trust, Oswestry, Shropshire SY10 7AG, UK

P Magnusson, Bone and Mineral Metabolic Unit, Division of Clinical Chemistry, Faculty of Health Sciences, Linköping University Hospital, Sweden

S Mohan, Musculoskeletal Disease Center, Jerry L Pettis VA Medical Center, Loma Linda, CA, USA

Correspondence to: Dr C A Sharp, chris.sharp@rjah.nhs.uk

Accepted 17 October 2003

\section{REFERENCES}

1 Li B, Aspden RM. Composition and mechanical properties of cancellous bone from the femoral head of patients with osteoporosis or osteoarthritis. J Bone Miner Res 1997; 12:641-51.

2 Brown SJ, Pollintine P, Powell DE, Davie MWJ, Sharp CA. Regional differences in mechanical and material properties of femoral head trabecular bone in health and osteoarthritis. Calcif Tiss Int 2002;71:227-34.

3 Fazzalari NL, Parkinson IH. Fractal properties of subchondral cancellous bone in severe osteoarthritis of the hip. J Bone Miner Res 1997;12:632-40.

4 Ashby MF. The mechanical properties of cellular solids. Metall Trans 1983;14A: 1755-69.

5 Mansell JP, Tarlton JF, Bailey AJ. Biochemical evidence for altered subchondral bone collagen metabolism in osteoarthritis of the hip. Br J Rheumatol 1997;36:16-19.

6 Mansell JP, Bailey AJ. Abnormal cancellous bone collagen metabolism in osteoarthritis. J Clin Invest 1998;101:1596-603.

7 Dequeker J, Mohan S, Finkelman RD, Aerssens J, Baylink DJ. Generalized osteoarthritis associated with increased insulin-like growth factor types I and II and transforming growth factor beta in cortical bone from the iliac crest. Possible mechanism of increased bone density and protection against osteoporosis. Arthritis Rheum 1993;36:1702-8.

8 Mohan S, Libanati C, Dony C, Lang K, Srinivasan N, Baylink DJ. Development, validation and application of a radioimmunoassay for insulinlike growth factor binding protein- 5 in human serum and other biological fluids. J Clin Endocrinol Metab 1995;80:2638-45

9 Miyakoshi N, Richman C, Kasukawa Y, Linkhart TA, Baylink DJ, Mohan S. Evidence that IGF-binding protein-5 functions as a growth factor. J Clin Invest 2001;107:73-81.

10 Mohan S, Jennings JC, Linkhart TA, Baylink DJ. Primary structure of human skeletal growth factor: sequence homology with human insulin-like growth factor-II. Biochim Biophys Acta 1988;966:44-55

11 Mohan S, Baylink DJ. Development of a simple valid method for the complete removal of insulin-like growth factor (IGF)-binding proteins from IGFs in 
human serum and other biological fluids: comparison with acid-ethanol treatment and C18 Sep-Pak separation. J Clin Endocrinol Metab 1995;80:637-47.

12 Fazzalari NL, Darracott J, Vernon-Roberts B. Histomorphometric changes in the trabecular structure of a selected stress region in the femur in patients with osteoarthritis and fracture of the femoral neck. Bone 1985;6:125-33.

13 Mohan S, Bautista CM, Wergedal J, Baylink DJ. Isolation of an inhibitory insulin-like growth factor (IGF) binding protein from bone cell-conditioned medium: a potential local regulator of IGF action. Proc Natl Acad Sci USA 1989;86:8338-42.
14 Bautista CM, Baylink DJ, Mohan S. Isolation of a novel insulin-like growth factor (IGF) binding protein from human bone: a potential candidate for fixing IGF-II in human bone. Biochem Biophys Res Commun 1991;176:756-63.

15 Mohan S, Baylink DJ. IGF-binding proteins are multifunctional and act via IGF-dependent and -independent mechanisms. J Endocrinol 2002;175:19-31.

16 Ueland T, Brixen K, Mosekilde L, Mosekilde L, Flyvbjerg A, Bollerslev J. Agerelated changes in cortical bone content of insulin-like growth factor binding protein (IGFBP)-3, IGFBP-5, osteoprotegerin, and calcium in postmenopausal osteoporosis: a cross-sectional study. J Clin Endocrinol Metab 2003;88:1014-18.

\section{Making Health Care Safer 2004}

21-22 October 2004

Royal College of Physicians, London

A two day conference for all professionals dedicated to providing safer health care for all.

Register now! Early booking discount available.

See website for details: www.quality.bmipg.com 